\title{
AKADÁLYOZOTTSÁG, SAJÁTOS NEVELÉSI IGÉNY ÉS PÁLYAVÁLASZTÁSI ALGORITMUS AZ IPOO-MODELL ALAPJÁN
}

\author{
Szerző: \\ Tudlik Csilla (Drs.) \\ Eszterházy Károly Egyetem
}

Szerző e-mail címe: csillatudlik@gmail.com

\section{Lektorok:}

\author{
Hanák Zsuzsanna (PhD) \\ Eszterházy Károly Egyetem \\ Mező Katalin $(\mathrm{PhD})$ \\ Debreceni Egyetem
}

...és további két anonim lektor

\begin{abstract}
Absztrakt
Gyakran hallani azt a kifejezést, hogy „bármi lehet belőled, még előtted áll az élet”. Ez a mondás valóban igaz lehet azokra, akik akadályozó tényezők nélkül indulnak útnak nyolcadikos vagy középiskolás korukban. Ám vannak olyan tanulók az oktatási rendszerben, akik erősen behatároltak személyiségbeli, tanulási, szociális vagy egészségügyi problémáik miatt. Ôk a sajátos nevelési igényú tanulók. Nem vonatkozik rájuk külön pályaválasztási jogszabály, mégis csak előre megszabott lépéseket tehetnek. Azaz algoritmus szerint történik a továbbtanulásuk, s az algoritmus az IPOO-modell alapján leírható.
\end{abstract}

Kulcsfogalmak: pályaválasztás, sajátos nevelési igény, algoritmus, akadályozó tényezők, IPOO

Diszciplinák: pedagógia, pszichológia

\section{Abstract \\ OBSTRUCTION, SPECLAL EDUCATION AND CAREER ALGORITHM BY IPOO-MODEL}

It is an often-heard expression „you can be whatever you want to, life is in front of you”. This saying might be true for those who start their way without obstacles. There are students in the system of education who are extremely limited by their personal, learning, social or health issues. They are student with special needs. No separate career regulation exists for them; but, they can follow the same predetermined footsteps as it is given for their peers with no special needs. Yet, further education and the career choices of children with special needs happen by a certain algorithm which can be defined by the IPOO-model.

Keywords: career orientation, special education, algorithm, obstructive factors, IPOO

Disciplines: pedagogy, psychology

Tudlik Csilla (2019): Akadályozottság, sajátos nevelési igény és pályaválasztási algoritmus az IPOOmodell alapján. OxIPO-interdiszciplináris tudományos folyórat, 2019/1, 61-73.

doi: 10.35405/OXIPO.2019.1.61 
Az oktatás minden szintje és formája érintett a sajátos nevelési igényű (SNI) tanulók ellátását illetôen. Óvodától a felsőoktatásig találkozunk az ún. SNI-s fiatalok képzési másságával. Gyakran nem másságként, hanem nehézségként élik meg a szereplők. Nehézség a szülőnek, aki nem érti, miért az ő gyerekét érinti. Nehézség a diáknak, aki érzi, hogy probléma van vele. Nehézség a tanárnak, mert nyilván sajátos hozzáállás szükséges. Továbbá nehézség a rendszernek, mert ellátásuk nem mindig megoldott a hiányzó szakemberek miatt.

A másság természetesen ezen diákok pályaválasztását is erősen befolyásolja. Már a sajátos ellátást nem igénylő tanulóknak is keretet szabnak az érdeklődési, képességbeli, értékbeli választások, a sajátos nevelési igényú tanulókra ez hatványozottan igaz. Az előbbieken túl a szakmaválasztást kizáró egészségügyi gondok vagy gyakran a nehezített tanulás miatt fellépó eredménytelenség bizonytalanítja el a fiatalokat. A közép- és felsőfokú oktatási intézmények részéről is érthetô a megfontoltság, hiszen nem egyszerúen a tanulmányaikat, de a későbbi munkavállalást is szem előtt kell tartaniuk.

A KSH előzetes adatközlése szerint a 2017-2018as tanévben 87411 fó SNI-s (integráltan oktatottat is beleértve) tanuló kezdte meg az évet Magyarországon. A sajátos nevelési igény helyzete érthetően foglalkoztatja az oktatás szereplöit. Képzésükkel, ellátásukkal és az ahhoz biztosított szakemberekkel számos tanulmány foglalkozik. Csépe Valéria (2008) és Tóth László (2015) a fogalom mögötti tartalom megismertetésével kezdi és az oktatási gyakorlatot veszi számba. A pályaválasztás szintén folyamatosan porondon van, de a legtöbb írás és kutatás (Szilágyi, Völgyesi, Zakar, Borbély-Pecze 2010, Hooley 2014) általános továbbtanulási témákkal, pályaválasztási összetevôkkel kapcsolatos. Bár egyre több dokumentum utal az általános tudnivalókon kívül, milyen összefüggés van a sajátos nevelési igény és a pályaválasztás között (Kőpatakiné, et.al., 2007), azért mindkét terület önállóan is bőséges témát rejt a szakemberek számára, ezek együttes vizsgálata azonban még tartogat kutatási lehetőséget. A legfrissebb munkák közül Török Réka (2017) nevét érdemes kiemelni, akinek vizsgá- lódási területe az SNI-s tanulók kilátásai és képzési lehetőségei.

Vizsgálatunk tárgyát képezi továbbá azon tanulók pályaválasztási lépéseinek leírása, akik egyéb akadályozottsággal élik mindennapjaikat, ám mégsem tartoznak a sajátos nevelési igény kategóriájába.

Jelen tanulmány első fejezetében az akadályozottságot, a sajátos nevelési igény fogalmát, ellátási helyzetüket és a pályaválasztás szempontjából fontos sajátosságokat taglaljuk. A második rész a lehetséges pályaválasztási algoritmusokat, lépéssorozatokat veszi számba, amelyek meghatározzák a döntéseket. Bemutatjuk az általános és az akadályozott, illetve sajátos nevelési igényú tanulók lehetséges eltérő algoritmusát, ezek leírása során pedig hivatkozunk a Mező Ferenc (2010) által felállított IPOO-modellre. Végezetül feladatokat fogalmazunk meg a folyamatban résztvevők számára.

\section{A sajátos nevelési igény és az akadályozottság}

A pályaválasztás szempontjából szükségesnek tartjuk tisztázni a sajátos nevelési igény és az akadályozottság fogalmak tartalmát.

A sajátos nevelési igényü tanuló a Nemzeti Köznevelésrôl szóló 2011. évi CXC. törvény szerint a kiemelt figyelmet, azon belül pedig a különleges bánásmódot igénylő gyermekek, tanulók közé tartozik (vö.: Mező és Mező, 2015):

a) különleges bánásmódot igénylő gyermek, tanuló:

aa) sajátos nevelési igényú (rövidítve: $\mathrm{SNI}$ ) gyermek, tanuló,

ab) beilleszkedési, tanulási, magatartási nehézséggel (rövidítve: BTMN) küzdő gyermek, tanuló,

ac) kiemelten tehetséges gyermek, tanuló,

Ezek közül az első kettő kategória - mely vizsgálatunk tárgya - meghatározása a következő:

aa) sajátos nevelési igényú gyermek, tanuló: az a különleges bánásmódot igénylő gyermek, tanuló, aki a szakértôi bizottság szakértői véleménye alapján mozgásszervi, érzékszervi (látási, hallási), értelmi vagy beszédfogyatékos, több fogyatékosság 
együttes előfordulása esetén halmozottan fogyatékos, autizmus spektrum zavarral vagy egyéb pszichés fejlődési zavarral (súlyos tanulási, figyelemvagy magatartásszabályozási zavarral) küzd,

ab) beilleszkedési, tanulási, magatartási nehézséggel küzdő gyermek, tanuló: az a különleges bánásmódot igénylő gyermek, tanuló, aki a szakértői bizottság szakértôi véleménye alapján az életkorához viszonyítottan jelentősen alulteljesít, társas kapcsolati problémákkal, tanulási, magatartásszabályozási hiányosságokkal küzd, közösségbe való beilleszkedése, továbbá személyiségfejlődése nehezített vagy sajátos tendenciákat mutat, de nem minősül sajátos nevelési igényűnek.

A pályaválasztás szempontjából - ahogy az Oktatási Hivatal honlapjának tájékoztatója is jelzi - az SNI és a BTMN kategóriák esetenként egynek számítanak, és SNI elnevezéssel utal rá, ezért tanulmányunkban mi is ezt az összefoglaló kifejezést használjuk.

Ellátásuk vagy az iskola keretein belül vagy kívül fejlesztő pedagógusok és gyógypedagógusok segítségével történik. A fejlesztésen kívül a tanórák keretében is biztosítani kell a problémának megfelelő támogatást: például magántanulói státusz megadása, segédeszköz engedélyezése, ültetési rend használata (látásproblémával küzdők esetén), differenciált feladatok, fel-mentés a tantárgy egésze vagy részleges értékelése alól.

Akadályozottság. Az akadályozottság olyan típusú egészségügyi probléma, amely nem tartozik sem a sajátos nevelési igény, sem a beilleszkedési, tanulási, magatartási nehézség körébe, ezért megállapítása nem befolyásolja az iskolai tanulást, ugyanakkor az állapot nagy hatással lehet a fiatal pályaválasztására és későbbi életére. Ilyen probléma lehet a krónikus légúti meg-betegedés, bőrbetegség, színtévesztés, magas vérnyo-más, szemüvegviselés, hogy csak néhányat említsünk.

\section{Sajátosság a pályaválasztás szempontjából}

A pályaválasztás fogalmát Szilágyi (2000, 16-17, idézi Fazakas, 2009) a következőképpen fogalmazta meg: „az egyén a fennálló lehetőségek alapján önállóan, céljának megfelelően kiválaszt egy olyan foglalkozást, tevékenységet, amely lehetôvé teszi, hogy a társadalom és/vagy a maga számára értéket tartalmazó munkát végezhessen. A hangsúly az egyén és környezete közti interakciós folyamaton van, amely folyamat döntéssel zárul, és ez adja a későbbi pályája kiindulópontját".

E döntés megtörténhet tanácsadói szolgáltatás igénybevételével is. Ennek keretében adottságok, képességek, irányultságok, érdeklődés, egyéni tulajdonságok vizsgálatával és foglalkoztathatósági, képzési információk nyújtásával segíti a tanácsadó a pályaválasztási döntés előkészítését és végezetül az iskolaválasztást.

A jogszabályok alapján mindenkire ugyanazok a jogok és kötelességek vonatkoznak, mégis külön figyelmet kell szentelni a sajátos nevelési igényú és akadályoztatott tanulókra a pályaválasztás során. Szerencsés, hogy a 20/2012. (VIII. 31.) a nevelésioktatási intézmények múködésérôl és a köznevelési intézmények névhasználatáról szóló EMMI rendelet a jogszabályon belül külön a sajátos nevelési igényre vonatkozó felvételi szabályokat fogalmaz meg (A középfokú iskolákba történő jelentkezés rendje és a felvételi eljárás szabályai), ugyanakkor pálya-/iskolaválasztáskor az egyéb akadályozottságot is figyelembe kell venni. Ez utóbbival azonban gyakran csak akkor szembesül a gyerek és szülő, amikor pályaalkalmassági vizsgálatra kerül sor.

\section{Készülés a középfokra}

Nagy tervezésre és előrelátásra van szükség a továbbtanulási tervek kivitelezéséhez függetlenül attól, hogy középfokon gimnáziumba vagy szakképzésbe készül a tanuló. A következőket érdemes végig gondolni:

- a megállapított sajátos nevelés nem kizáró ok-e a választott szakmában,

- mely iskola tud sajátos nevelési igényú tanulót fogadni,

- megírja-e a tanuló a központi írásbeli felvételit,

- igényelni kívánja-e az írásbelit tartó intézménytôl a megállapított segítséget.

A gimnáziumba készülők valamivel kedvezőbb helyzetben vannak, ugyanakkor, ha távlati célokban 
gondolkodnak, a fentiek rájuk is érvényesek. Például: egy színtévesztő tanuló jól elboldogul a gimnáziumi környezetben, viszont későbbi választásait ismét befolyásolhatja a problémája akár felsőoktatásba, akár szakmaszerzésre készül.

A szakképzésben erőteljesebben jelenik meg a probléma, bizonyos szakmáknál kizáró ok lehet például a mozgáskorlátozottság, látásprobléma, hallássérülés, színtévesztés és az asztma, hogy néhány kézenfekvő dolgot hozzunk elő. Egyrészt nem érdemes olyan intézményt választani, amely nem tudja biztosítani a sajátos nevelési igény kezelését. Hiába írja elő a jogszabály a fejlesztést, ha az iskola szakember híján nem tudja azt biztosítani. Másrészt kiderülhet, hogy sajátossága vagy akadályozottsága miatt nyilvánvalóan nem képes majd az iskola által kínált szakképzés komplex vizsgáját letenni vagy későbbi munkájában múködni.

Amennyiben olyan intézményt választ a tanuló, amely kéri az írásbeli felvételit, az SNI-s tanulónak is kötelező megírnia, függetlenül például a matematika tantárgy értékelése alóli felmentésétôl. Az más kérdés, hogy a felvételi pontszámokat a választott iskolák hogyan, milyen arányban számolják be. Könnyen elképzelhető tehát, hogy három olyan gimnáziumot választ majd a tanuló, ahol elvárják az írásbeli megírását, de a számításnál a magyar eredményt duplázzák, vagy a matematika jegyen kívül más jegyet számítanak be, vagy eltekintenek a felvételi megírásától, de a teljes tanulmányi eredményt veszik figyelembe. Ennek eldöntéséhez azonban a szülőnek valamennyi iskolával egyenként kell egyeztetnie a lépéseket.

A szakképzésben egészségügyi és pályaalkalmassági vizsgálatra is sor kerül, tehát egyértelmúvé válik, hogy finommechanikai múszerészként nem tudja majd teljesíteni a követelményeket ujjak részleges vagy teljes hiányában, vagy pékként, ha mentesítve van mennyiségek számítása alól.

\section{Készülés a felsöfokera}

A felsőoktatásban való továbbtanulás kevésbé kizáró jellegú, hiszen itt gyakran nem kerül a hallgató egészségügyi vagy pályaalkalmassági vizsgálat alá, viszont későbbi munkájánál az üzemorvos eltilthat- ja a későbbi munkavégzéstől, ezért érdemes továbbra is alaposan átgondolni a lehetóségeket. Azonban vannak olyan szakterületek, amelyeknél az egyetemek egyetér-tésre jutottak abban, mi lehet tanulmányok végzésétól eltiltó ok. A legszigorúbb eljárások az államtudományi és a pedagógia területén vannak. Több egészségügyi okon kívül egyértelműen kizáró az úgynevezett „disz” legtöbb fajtája (főként: diszlexia, diszgráfia, diszkalkulia). Ezek esetében iránymutatást ad a felvételi tájékoztató, ám egyes szakoknál nem könnyú az eligazodás.

\section{Pályaorientáció \\ az IPOO-modell aspektusából}

$\mathrm{Az}$ algoritmus vagy a pályaválasztási döntés meghozatalának menete értelmezhető az IPOOmodell (Mező, 2010) alapján is. Az IPOO (Input, Process, Output, Organizáció) fogalmát Mező Ferenc vezette be 2010-ben annak leírására, hogy a tanulók hogyan szerzik, dolgozzák fel, szervezik és produkálják ismereteiket a tanulás, teljesítmény és tanulásmódszertan terén. Valójában a pályaválasztási döntés is egy ilyen tanulási folyamatnak fogható fel, s az IPOO részei vonatkoztathatók rá:.

1. Az algoritmus minden utasitása az Input (=információ bemenet) része, hiszen a tanuló információt nyer érdeklődéséről, képességeiről, pályákról és munkaerőpiacról.

2. Kevésbé követhető szakasza a folyamatnak a Process (=infomrációfeldolgozás), mivel annak mozzanatai gyakran külsőségekben nem nyilvánulnak meg. Ugyanakkor, ha a pályaválasztási algoritmusra egyéni tanácsadásként (és egyben az Organizáció, vagyis a szervezés elemeként) tekintünk, máris felfedezhetjük a feldolgozás eseményeit. Ezek a következők lehetnek:

- visszakérdezés (általában a Milyen? és a Mit csinál? kérdőszóval bevezetve, például „Milyen az X iskola?”, „Mit csinál egy gépészmérnök?” stb.), 
• önálló mondatszerkesztés a „ha” kötőszóval (például „Ha X iskolába megyek, a szakmámmal több pénzt kereshetek".),

- listakészítés (például tanácsadó segítségével lehetséges szakmalista összeállitása),

- kizárások (például a döntési folyamat részeként a tanácsadó segítségével a legkevésbé valószínú választások kihúzása a listáról),

- ismétlések (például a kliens önmaga meggyőzésére vagy az információk tudatosítására elismétli a kapott információt),

- meggyőzés (például érvek felsorakoztatásával eléri a szülő egyetértését).

3. A jól felépített tanácsadás Output (=kimenet) része lehet talán a leglátványosabb, hiszen a tanuló - legalábbis ez a cél - lehetséges listával, választható iskolai rangsorral vagy elvégzendő pályaválasztási teendők listájával távozik.

Azért is érdekes a modell, mert diagnosztikai és fejlesztő eszközként is használható a pályaválasztási döntéshez vezetô út korai szakaszában. Másrészt: a pályaválasztási folyamat algoritmizálható, s ez az algoritmus a pályaválasztási döntést megalapozó információfeldolgozással azonosítható.

\section{Az algoritmus}

Azt a folyamatot, amikor egy probléma megoldása érdekében meghatározott lépések sorozatát hajtjuk végre, algoritmizálásnak nevezzük. Az algoritmus a legáltalánosabb értelemben tervszerűséget jelent. Ha egy elvégzendő cselekvéssorozatot lépésről lépésre átgondolunk, akkor algoritmust készítünk egy adott cél elérésére. A lépéseket egyesével, pontos szabályok szerint hajtjuk végre. Egy másik megfogalmazás szerint: egy algoritmusban megadjuk egy feladat véges számú lépésben végrehajtható megoldását. A feladat megoldásánál felmerülő ötleteinket utasításokká alakítjuk, melyek összessége algoritmust eredményez. (Oktatási Hivatal - Sulinet Tudásbázis, 2008) A leírás alapján tehát a döntéshez vezetô pályaválasztási tevékenységnek is létezik algoritmusa. Van egy megoldásra váró probléma (pálya kiválasztása), melyhez meg kell tervezni a megfelelő lépéseket az eredmény érdekében. A tanácsadási naplók nagy többsége ezt a folyamatot járja végig.

\section{Lehetséges pályaválasztási algoritmusok elemző vizsgálata}

Jelen tanulmány arra vállalkozik, hogy az SNI-s vagy akadályozott tanulókkal kapcsolatba kerülóknek, tanácsadóknak, tanároknak támogatást nyújtson a döntéshelyzetek előtt. A folyamat megértésével elkerülhetók az olyan csapdák, amelyek a tanácstalanság, az ismerethiány, vagy a nem megfelelő lépések megtétele miatt alakulnak ki. Vizsgálatunkban a pályaválasztási döntéshez vezető út általános lépéseit követtük nyomon hetedikes, nyolcadikos és középiskolás tanulóknál.

Az a hipotézis fogalmazódott meg, hogy a pályaválasztási döntés menete a vizsgált minta alapján előre megrajzolható, tervezhető folyamaton alapul, lépései leírhatóak, algoritmust alkotnak, ugyanakkor az SNI-s és akadályozott tanulók esetében ezek a lépések eltérőek. Abban azonban nem mutatkozik különbség, hogy az azonos ponton történő beavatkozással sikerességük növelhető.

\section{Minta}

A Szabolcs-Szatmár-Bereg Megyei Pedagógiai Szakszolgálat továbbtanulási, pályaválasztási tanácsadójának egyéni tanácsadási anyagai került górcső alá 2018 júniusa és novembere között ( $\mathrm{n}=117$ fó). Közülük 58 fő́t emeltünk ki érintettként, 9 fő SNI-s szakértói véleménnyel rendelkezik, 9 főnek továbbtanulást erősen befolyásoló egészségügyi problémája van, 12 pedig mindkettóben vagy többszörösen érintett tanuló, a többiek problémája pedig vagy kezelhető a pályaválasztás szempontjából vagy nem olyan mértékủ a befolyása. A sajátos nevelési igényú és akadályozott tanulók anyagaiból hat került példaként kiemelésre, melynek válogatási alapja az eltérő sajátosság bemutatása volt. A pályaválasztás szempontjából a sajátosság típusát és mennyiségét vettük figyelembe.

A vizsgálat során az általános iskolás és középiskolás korosztály anyagaiból is merítettünk, ugyanakkor nem vettük figyelembe a tanulók hátterét 
(például iskoláját vagy szociális hátterét), mivel tapasztalataink szerint nem mutatható ki összefüggés a háttér és magának a pályaválasztási döntésnek általános folyamata, lépéssorozata között. Azaz bármilyen legyen is a család egzisztenciája vagy a szüló képzettsége, a lépések egymásutánisága nem változik.

Nem tértünk ki továbbá a nemek szerinti vizsgálatra, hiszen - bár eltérés mutatkozik a fiúknak és lányoknak kínált továbbtanulási lehetőségek számában - az nem befolyásolja magának a pályaválasztási folyamatnak a menetét.

\section{Módszer}

A vizsgálat során a szóbeli tanácsadás mellett számos írásbeli feladatot is megoldottak a tanulók. Ezek funkciója, hogy részletesebben feltárják a tanácskérő érdeklődését, képességét, munkaértékét, tanulási módszerét. Ezeken kívül a tanácsadási naplóba került a tanuló iskolai jegye, hobbija, egészségügyi állapota, saját továbbtanulási elképzelései, valamint a tanácsadó jegyzetei a tanulóval és annak munkájával kapcsolatban. A személyiség egyes területeinek feltárására az 1. táblázatban látható eszközöket használta a tanácsadó.

1. táblázat: Pályaválasztási tanácsadás során használt esqközöo (forrás: a Szerző)

\begin{tabular}{|c|c|c|}
\hline Téma & Általános iskolás korosztály & Középiskolás korosztály \\
\hline Érdeklődés & $\begin{array}{c}\text { Érdeklődés (átdolgozott), Holland érdeklődési } \\
\text { kérdő́iv, Pályaterületek }\end{array}$ & $\begin{array}{c}\text { Karriertábla, Miskolci rövidített, Skawran II., } \\
\text { Pályaterületek, Holland érdeklődés kérdốv }\end{array}$ \\
\hline $\begin{array}{c}\text { Képességek- } \\
\text { készségek }\end{array}$ & $\begin{array}{c}\text { Képességek, készségek (hosszú változat), Te- } \\
\text { vékenységek-képességek, Konkrét térelképze- } \\
\text { lés, Szemmérték, térbeli gondolkodás (utóbbi } \\
\text { kettő opcionális) }\end{array}$ & $\begin{array}{c}\text { Tevékenység-képesség, Képességek, készségek } \\
\text { (hosszú változat) }\end{array}$ \\
\hline Értékek & Munkavállalási érték kérdőív & Super munkaérték kérdőív \\
\hline Tanulás & Tanulásdiagnosztika & Tanulásdiagnosztika \\
\hline
\end{tabular}

\section{Általános algoritmus}

Normál esetben világos algoritmussal állunk szemben (1. ábra), ahol nincsenek eltérítő tényezők, adottak a feltételek, nincs vagy kevés beavatkozásra van szükség. Ha egy példán keresztül szeretnék láttatni, a következő lépésekre kerülne sor (a magyarázat érdekében jelenleg sűrítve):

14 éves lány szererti a papirmunkát, a rendszerezést, az irodai tevékenységeket, szeret számokekal foglalkozni. Matematikából igen jó jegyei vannak, és életkoráboz viszonyítva tisztában van vele, mivel foglalkozile a könyveló. Ismeretek szerint a pénzügyekekel foglalkozók megtalálják helyüket a munkaeröpiacon, igy a szülók támogatását is élveri. A közelben van is ilyen kép rést folytató intézmény, melynek. nyill napján csak megerösödike elhatározásában, s eldönti, oda adja be jelentkezését.
Akkor tekintjük eredményesnek az algoritmust, ha nem csak megtaláltunk egy pályát, hanem az a pálya személyiségünknek, vágyainknak megfelel, adott esetben még a munkaerőpiachoz is illeszkedik. A felsorakoztatott lépéseket akkor te-hetjük meg, ha annak feltételei biztosítottak, például pályaérettség megfelelő foka, képesség-faktorok szintje (ide értve most a tanulmányi jegyeket is), munkatapasztalat, pályaismeret, családi kötöttségek szintje. Amikor a feltétel nem teljesül, beavatkozásra van szükség. A beavatkozás történhet tanácsadó, tanár, szülő, papír vagy online formátumú információforrás által. Az 1. ábra 4. és 5. lépése esetében akár a teljes folyamat újraindításáról is szó lehet, hiszen a munkaerôpiac és a család elképzeléseihez újra át kell gondolni, mennyire érdeklődik az illető a tevékenység iránt, megvan-e a képessége hozzá, van-e ismerete róla és így tovább. 
1. ábra: Altalános pályaválasz̧ási algoritmus (forrás: a Szerzö)

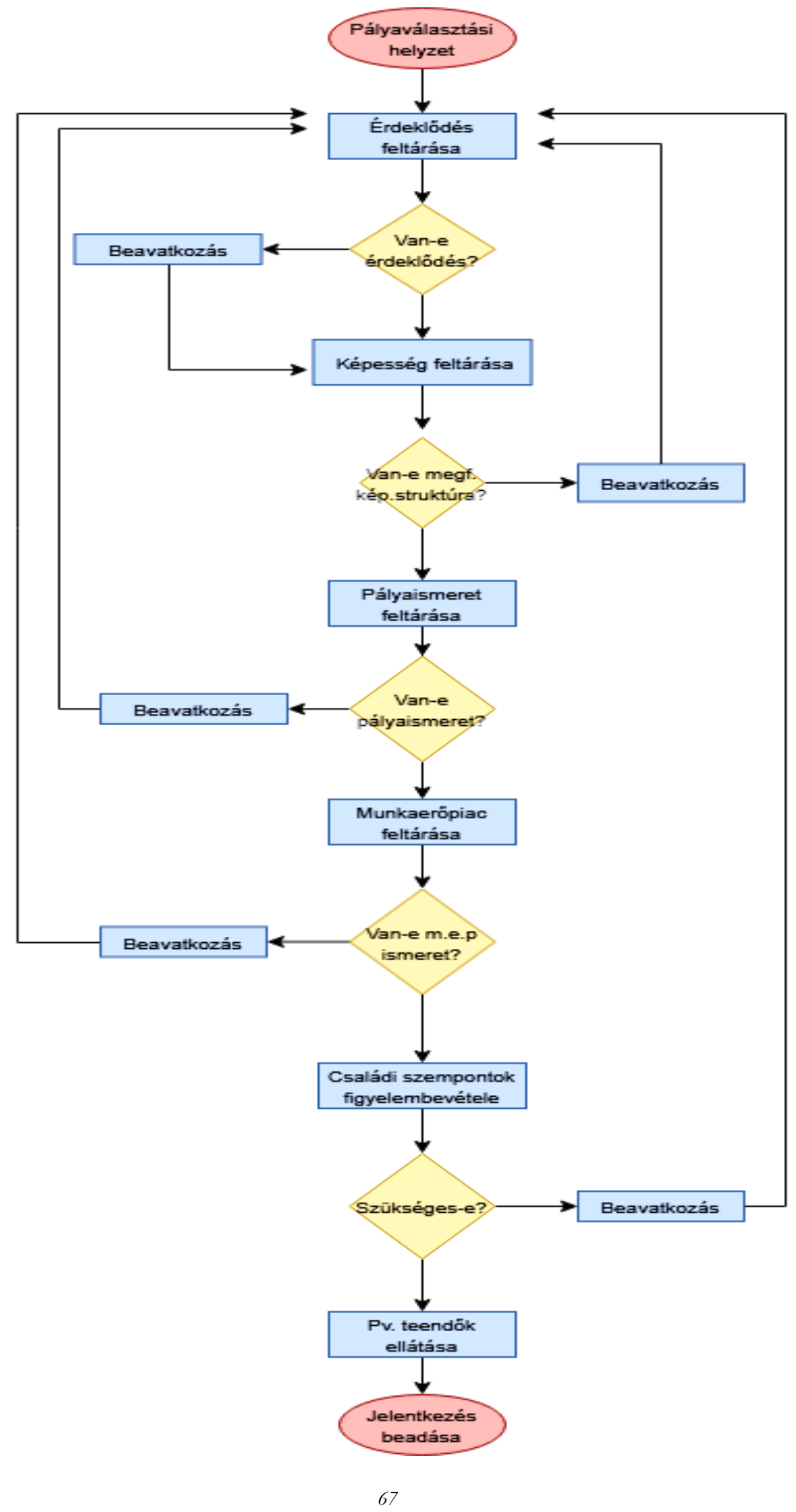


A lépések sorrendje az 1. ábra 1-5. lépése esetében felcserélhetô, mivel könnyen elképzelhetô, hogy a munkaerő-piaci megfontolás az elsődleges, vagy a pályaismeret bővítése révén alakul ki az érdeklódés, esetleg erős a családi indíttatás. Az algoritmus többször ismétlődhet életünk során, legkevesebb egyszer (ha felsőoktatásban tanulunk tovább érettségi után), de sokszoros lehet, ha még egy vagy több szakmát is szeretne a személy, szakmaváltás vagy másod-/harmaddiploma megszerzésére kerül sor.

\section{„Sajátos” algoritmus}

Sajátos nevelési igény és akadályozottság esetén értelemszerűen erős befolyásoló tényezőkkel kell számolni. Gyakran az SNI vagy az akadályozottság mértéke és milyensége irányítja a döntéshez vezetó utat, s nem az érdeklődés. Ilyen esetben a pályaválasztási algoritmus a 2. ábrán látható módon alakul. Képességek alatt itt mindazt a bázist értjük, amivel a gyerek rendelkezik, tehát építeni lehet rá, ugyanakkor azt is, ami a sajátos nevelési igény körébe tartozik (pl. diszkalkulia vagy mozgáskorlátozottság), a körébe nem tartozó, de akadályozókat (pl. színtévesztés, asztma), valamint a tanulási képesség egyik megmutatkozásaként értelmezett tanulmányi eredményt is.

A 2. ábra érzékeltetésére álljon itt néhány példa a hat vizsgált tanácsadói anyagból:

N. N. középiskola 10. évfolyamán tanul gimnáziumban. Jegyei viszonylag jók (3, 4 és 5 váltakorik), viszont felmentett matematikából, továbbá más tárgyak számolási feladatai alól. Térben rosszul tajjékoródike, labdajátékok alól is felmentett, valamint tompán látó, egyik szemén 20\%-ot, másikon 80\%-ot lát. Van elképzelése arról, hogy gyerekekkelel és/vagy idegen nyelvekkel akar foglalkozni. Jelenlegi javaslat: szociális munkás, romanisztika, közösségszervezés. (Jegyei, amelyek még nem reménytelenül javithatatlanok, lehetövé teszik a felsófok felé lépést.)

B. B. általános iskolában nyolcadikos tanuló, közepes eredményü, viszont asżtma-allergiával rendszeres kezzelés alatt áll. A krónikus betegség sok területen kizáró ok, kïlönösen az általa elképzelt pék szakmában. Viszont szereti

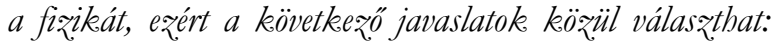
logisztikea, finommechanika, számitógép-szerelo". (Jegyei kis javitásával a szakkörépiskolai képrésen kivül a szakgimnázium is elérbetó.)

D. K. (1) általános iskolában hetedikes, enyhe szemüveget visel, várhatóan disžalkuliával felmentik (jelenleg a szakértöi határozatra vár), tanulmányi eredménye kifejezet ten ross: Nincs elképzelése továbbtanulását illetöen, de anyagából kiderül, hogy a szerelés kedvére lenne. Az úgynevezett fiús szakmák jó részéböl a matematika felmentése miatt ki lesz zárva, továbbá a müszaki érzéke vizsgálatnál sem mutatott jó eredményt. Így függetlenül a kedvtól azokera támaszkodhat, ami megengedhetö pl. merógazdasági terület. (Látható, hogy bár két akadályoztató tényezôvel állunk szemben, jobb jegyek birtokában a választható lista kiböovülne.)

H. M. O. egy általános iskola betedik osztályos tanulója. Viszonylag jól tanul, 3, 4, 5 közööt változile a jegye. Több nyelven beszél, külföldön született és kezdte el az iskolát. Bár megállapitották a diszkalkuliát, a sұülō kérésére nem mentették fel, és a matematika jegye hármas. Ezen kiviul gyenge szemüveget visel és szintévesżtô. Elmondása szerint elég komoly tervei vannak, anyaga is kiegyensúlyozott teljesitményt mutat. Egyelöre a gimnáziumi javaslatot kapta jegyei erösitésével. (A jó jegyek és kedveró képességfaktorok biatositékai lehetnek a továbbtanulásra.)

D. K. (2) betedik osztályos tanuló egy alapitványi iskolában. Igen rossz értékelései vannak az intézményböl, matematikából felmentett, továbbá ADHD-t állapitottak meg nála, melyre gyógyszeres kezzelést kap. Az iskola sajátosságaiból adódóan erösen müvészi beállitottságú, jó a kézügyessége. A fentiek alapján a kerámiamüves, virágkötö, disznövénykertész, kertész, szakeképzés javasolt, mivel nem jelenlegi iskolájában kivánja folytatni tanulmányait. (A rossz jegyek és a többsqörös bátráltatás les₹úkititi a lehetséges pályák listáját, mivel erös koncentrációt, számolást és tanulási képességet igénylö területek nem jöhetnek szóba.)

T. M. A. nyolcadik osztályos tanuló. Gyenge tanulmányi eredménye van, idegen nyelvböl felmentett, a disžkalkulia és diszlexia is megállapitásra került, de a szülö kérésére nem mentették. fel. Vannak elkép zelései, korához képest vannak. ismeretei a szakmákról, müszaki érzéke, térlátása megfeleló. Anyaga szerint az as₹talos, kárpitos szakmai javaslatot kapta, mivel a választott intézmény tud fogadni SNI-s ta- 
2. ábra: SNI és akadályozott pályaválasztási algoritmusa (Tudlik, 2018)

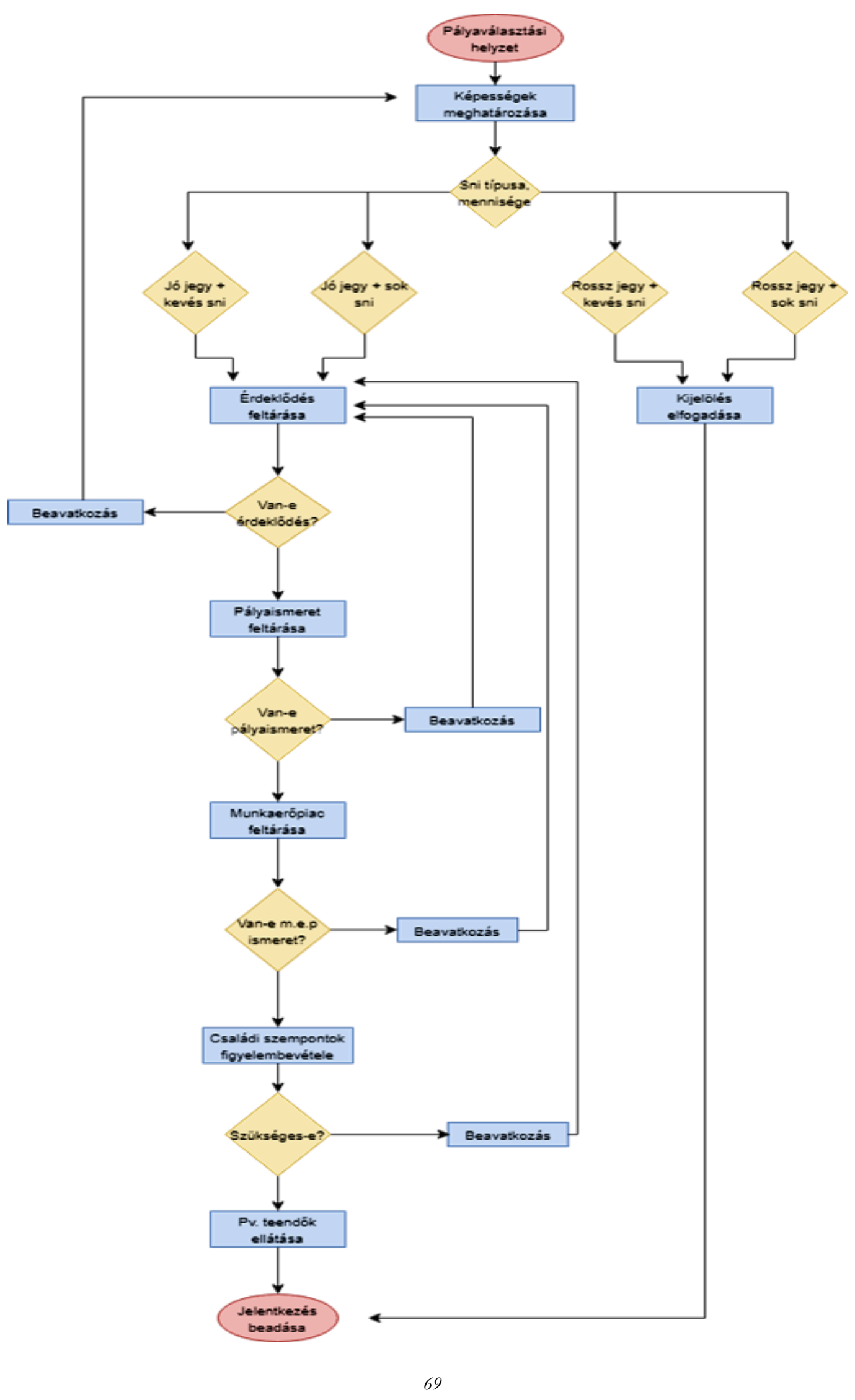


nulót. (Gyenge jegyekekel bir ugyan a tanuló, de más képességei elötérbe tudja helyezni, illetve egyéb egészségügyi probléma nem merült fel, igy egy sqámára elfogadható ,fiús" sqakma elérhetó.)

A tanácsadási naplókból az általánosítható, hogy akár van előzetes elképzelése, érdeklődése a tanulónak, akár nincs, a sajátos probléma felől tudjuk megközelíteni a szükséges lépéseket. Nem azért, mert ezek a tanulók nem bírnak pozitív értékekkel, viszont az SNI és akadályozottság milyensége és mértéke felülírhatja az elképzeléseket. Buzdíthatjuk N. N.-t, hogy ha minden vágya, hogy gyerekekkel foglalkozzon, akkor legyen óvónő vagy tanító, de az ő sajátossága (különösen így többszörösen) nem teszi lehetôvé az elképzelését, mivel a szakma pályaalkalmassági követelményeinek nem felel meg. B. B. lehetőségei sem azért korlátozottak, mert nincs álma, hanem mert a jelenlegi egészségügyi követelmények értelmében azon a területen nem tud majd biztonsággal múködni. Viszont mindkettôjüknél megállapítható, hogy egyéb képességek pl. a tanulás - fejlesztésével bővíthetők a lehetôségek. Tehát N. N.-nek tanulás-módszertani segítségnyújtással van lehetősége tanulmányi eredménye növelésére, s így egyéb felsőfokú képzésben való részvételre, B. B.-nek pedig - szintén a jegyek javításával - kibővült volna a választási palettája például szakgimnáziumi képzésekkel.

\section{Következtetések}

Török Réka (2017) kutatásában rámutatott, hogy nincs különbség a normál fejlődésû és sajátos nevelési igényű tanulók önmegvalósítási vágyai között, azaz nem állapítható meg, hogy az utóbbi csoport kevésbé pozitív hozzáállású, vagy nagyobb a bizonytalanságuk jövőjükkel kapcsolatban. Viszont az SNI-s csoport alacsony pályadöntési énhatékonyságát leginkább a tanulmányi eredmény és a tanácsadás hiánya befolyásolja. Már 2007-ben Kőpatakiné és szerzőtársai is azt közölték kutatásukban, hogy a sajátos nevelési igényú tanulókat a felvételi vizsga eredménye, a tanulmányi eredmény és (még ha felvételt is nyer a kiválasztott iskolába) ez utóbbi romlása miatt a lemorzsolódás fenyegeti.

A tanácsadási naplók áttekintése és az eredmények összefüggéseinek feltárása során a következő megállapítások vonhatók le a „sajátosság” milyensége és mértéke, valamint a tanulmányi eredmény figyelembevételével:

1. Minél több és súlyosabb a sajátos nevelési igényre és akadályozottságra vonatkozó probléma (ami rossz tanulmányi jegyekkel is társul), annál nagyobb annak a veszélye, hogy a tanuló nem tud a tényleges érdeklődésének megfelelő irányban elindulni. Azaz olyan szituáció áll eló, amikor már nem elsődleges a gyerek vagy a szülő vágya, esetleg munkaerô-piaci szempontból helytálló-e a döntés, sokkal inkább kompromisszumra lesz szükség a további tanulmányokhoz (D.K. (1) és D.K. (2) tanulók).

2. Sok ugyan a befolyásoló tényező, de a jegyek viszonylag jó tartományban vannak, esetleg még elképzelése is van a tanulónak vagy a családnak, ebben az esetben nem kizárt az algoritmus 3. lépéséhez (érdeklődés feltárása) való visszatérés, azaz nagyobb a szó szerint érthető választási lehetôség (N. N. és H. M. O. tanulók).

3. Lehet, hogy kevés számú és/vagy súlyú akadályozottsággal és sajátos nevelési igénnyel él a gyerek, de ha kifejezetten rossz tanulmányi eredmény társul hozzá, szintén kompromiszszumra lesz szükség továbbtanuláskor (T. M. A. tanuló).

4. Viszonylag jó jegyek mellett kevés vagy nem súlyos sajátosság áll, akkor ismét az algoritmus 3. lépése következhet, vagyis kitágul a lehetőségek köre (B. B. tanuló).

Ezek értelmében három folyamatszereplőnek jelölhetô ki feladat:

1. A diákoknak: Akár kevés, akár többféle sajátos nevelési igényre jogosító gonddal küzd a tanuló, az egyetlen „menekülési” útja a jegyek javítása és a tanulás iránti attitűdjének megváltoztatása lehet. Mi- 
nél jobb a tanulmányi eredménye, annál nagyobb választási lehetőséget biztosít saját magának.

Jelen tanulmányban nem térünk ki olyan mérés metodikai kérdésekre, hogy az osztályozás mennyire valós tudást jelez, csak azt tudjuk megállapítani, hogy aktuális felvételi rendszerünkben a jegyek fontos szerepet töltenek be.

2. Az iskoláknak: Nagyobb gondot és idôt kell fordítani a tanulásdiagnosztikára - tanulásfejlesztésre.

Számtalan diagnosztikai szakember és eszköz áll rendelkezésre, hogy az iskola - saját eredményessége érdekében is - igénybe vegye ezeket. Itt ismét vissza kell utalnunk az IPOO-modellre, amely nemcsak a teljes algoritmus szintjén, de a tanuló szintjén is értelmezhető mint lehetséges diagnosztikai és fejlesztési módszer. Minél inkább tisztában vagyunk a tanulást gátló tényezőkkel, annál célirányosabban tervezhetjük az ezek kiküszöbölésére irányuló fejlesztést, ami rövid és hosszú távon is javíthatja az iskola hozzáadott értékét.

3. A tanácsadóknak és szakembereknek: A kényszerpályára került tanulóknak úgy szükséges bemutatni és megismertetni az adott szakterületet, hogy megindulhasson majd a pályaidentifikáció, s ez nagy feladat. El kell érni, hogy ebben a kényszerhelyzetben ne riassza el, hogy egyelőre még nem érdeklődik a terület iránt, hogy lássa maga előtt a fejlődési lehetôségeket, és idôvel el tudja magát képzelni a pályán. E cél elérését segíthetik a tantárgyba ágyazott pályaorientáció, a tanácsadás igénybevétele, szakmabemutató filmek, munkatapasztalat szerzése, üzemlátogatás, csak hogy néhányat említsünk.

Tanulmányunkkal arra kívántuk felhívni a figyelmet, hogy a pályára készülés valamennyi összetevőjét (önismeret, pályaismeret, munkaerő-piaci ismeret) érinti az akadályozottság és/vagy sajátos nevelés igény mértéke és milyensége, továbbá az erőfeszítések sikerességét nagymértékben befolyásolja a tanulmányi eredmény. Az elsôn azzal lehet segíteni, ha idejekorán felméri a család és gyerek az erőforrásokat, a másodikon pedig a gyerekek tanulásmódszertani felruházásával, hiszen ez eszköz lehet az előrejutásban.

\section{Konklúziók}

A tanulmányban az akadályozott és sajátos nevelési igényű tanulók pályaválasztási döntéshez vezető folyamatát vizsgáltuk. Az első részben a sajátos nevelési igény fogalmát, ellátási rendszerét mutattuk be. Itt kapott helyet a pályaválasztás szempontjából fontos jogszabályi keret, amely - bár nem különbözteti meg kötelezettségeit tekintve az SNI-s tanulókat - jogok tekintetében pozitívan viszonyul ezen diákokhoz. A második fejezetben a vizsgálat tárgyát képező anyagokat mutattuk be. A szakszolgálati tanácsadási naplók segítségével feltárult a pályaválasztási algoritmus szerkezete. Megkülönböztettünk úgynevezett általános és sajátos nevelési igényủ pályaválasztási algoritmust. Végezetül az összefüggések láttatásával lehetséges feladatokat határoztunk meg a folyamat résztvevői számára.

Az eredményeket úgy fogalmazhatjuk meg, hogy a sajátos nevelési igénnyel bíró és akadályozott tanuló esetében döntő pályaválasztási szempont a sajátosság típusa és mértéke, továbbá tanulmányi eredményének függvénye lehet a szabad vagy kényszerválasztás.

A pályaválasztási folyamat megkönnyíthető, és annak valamennyi résztvevője hozzájárulhat lehetőségeihez mérten. Bár a diákoknak nem győzik a tanárok hangsúlyozni, mennyire fontos a tanulás és a jó jegy, de a vizsgálat megmutatta, hogy az alacsony szintû tanulmányi eredményesség - különösen a sajátossággal küzdőknél - hamar lezárhatja, korlátozhatja a döntési folyamatot. Az iskola abban vállalhat nagyobb részt, ha korai szakaszban tanulásdiagnosztikai mérések által képet kap a tanulók szokásairól, hibáiról, hiányosságairól, s ezek ismeretében támogatják a tanulók jobb jegyekért történő törekvéseit. A korai szakasz egyértelmúen a pályaválasztási döntés előtti 4-5 évet jelenti. A szakemberek pedig reményt adhatnak azoknak a diákoknak, akik - akármilyen nagy is a küzdelem - talán éppen sajátos nevelési igényüknél fogva nem képesek a jobb eredményre.

A vizsgálat során nem tértünk ki kifejezetten a sajátos nevelési igényúek és akadályozottak tanulásfejlesztési lehetőségeire, viszont felhívtuk a figyel- 
met egy jól használható elméleti keret (az IPOOmodell) alkalmazására.

Több kutatás bizonyította ugyan, hogy a diákok háttere és pályaválasztási döntése között szoros összefüggés van (Lannert 2004, Liskó, 2003, 2004, Olteanu 2015, Szentes 2016), azonban jelen vizsgálatban nem találtunk bizonyítékot arra, hogy a szüló iskolázottsági szintje vagy anyagi háttere alapjaiban megváltoztatta volna a döntéshez vezetó algoritmus lépéseit. Továbbá nem voltunk tekintettel a fiú-lány különbségekre abból a megfontolásból, hogy magát az algoritmust nem befolyásolja a tanuló neme.

Vizsgálatunk ugyan csak egy megye szakszolgálatának pályaválasztási tanácsadási anyagát dolgozta fel, de feltételezésünk szerint valamennyi ellátási helyen ugyanilyen pályaválasztási algoritmus tapasztalható, ennek megerősítésére további vizsgálatok szükségesek.

\section{Összefoglalás}

A fentiekben a következő témák kerültek megvilágításra: akadályozottság, sajátos nevelési igény és sajátosság a pályaválasztás szempontjából. Kitértünk arra, hogy a pályaválasztási döntés egyes lépéseit kívánjuk megvizsgálni. A jogszabály egyértelmű megfogalmazást ad arra, ki számít sajátos nevelési igényűnek, illetve a pályaválasztás szempontjából ezen fogalom alá értjük a beilleszkedési, tanulási és magatartási zavarral küzdőket is, továbbá a vizsgálatunkat képező lépéssorok érdekében a nem látható egészségügyi problémákat is számba vesszük. Rámutattunk, hogy külön eljárások vonatkoznak a középfokra és a felsőfokra készülőkre, s abban is eltérés mutatkozik, milyen komolyan veszik figyelembe a sajátos nevelési igény vagy akadályozottság meglétét.

\section{IRODALOM}

Adonyiné, Gábori M. (2006). A sajátos nevelési igényú gyermekek integrált/inklúzív nevelése. In Bárdossy,I., Forray R. K. \& Kéri, K. (szerk.). Tananyagok a pedagógia szakos alapképréshez. PTE BTK Neveléstudományi Intézet, Pécs, 213-235.
Bánfalvy, Cs. (2008) (szerk.) Az integrációs cunami. Tanulmányok a fogyatékos emberek iskolai és társadalmi integrációjáról. ELTE Eötvös kiadó, Budapest.

Borbély-Pecze, T. B. (2010) (szerk.). Az életúttámogató pályaorientáció rendszerének bevezetése $M a$ gyarországon Életpálya-tanácsadás (Lifelong Guidance). TÁMOP 2.2.2. A pályaorientáció rendszerének tartalmi és módszertani fejlesztése Foglalkoztatási és Szociális Hivatal

Borbély-Pecze, T. B. (2010) Életút támogató pályaorientáció. A pályatanácsadás szerepének, tartalmának, müvelōi körének kiszélesedése és pedagógiai fejlesztésének lehetóségei. ELTE PPK, PhD értekezés.

Csépe, V. (2008). A különleges oktatást, nevelést és rehabilitációs célú fejlesztést igénylő (SNI) gyermekek ellátásának gyakorlata és a szükséges teendők. In Fazekas,K., Köllő, J. \& Varga, J. (szerk.). Zöld könyv. A magyar közoktatás megúijtásáért. Budapest. ECOSTAT. 139.

Fazakas, I. (2009) Az iskolai pályaorientációs feladat új módszertani lehetöségei. Doktori disszertáció. ELTE-PPK.

Hooley, T., Matheson, J., \& Watts, A. G. (2014) Advancing ambitions: The role of career guidance in supporting social mobility. The Sutter Trust. University of Derby

Hooley, T. (2014) The Evidence Base on Lifelong Guidance: A Guide to Key Findings for Effective Policy and Practice. Jyväskylä, Finland: ELGPN

Kolozsvári, Cs. (2017). Tanulási nehézség kategóriába sorolt tanulók továbbtanulási elképzelései. In Karlovitz, J. T. (szerk). Válogatott tanulmányok a pedagógiai elmélet és szakmódszertanok köréból. IRI. 110-115.

doi: 10.18427/iri-2017-0017

Kőpatakiné, Mészáros M., Mayer, J., Németh Sz., Singer, P., Szilassy E. \& Vargáné Mező L. (2007). Akadálypályán. Sajátos nevelési igényü tanulók a középfokú oktatásban. Budapest, SuliNova Kht.

Központi Statisztikai Hivatal (2017) Oktatási adatok 2017-2018. Statisztikai tükör (december 22.) (Letöltés: 2018. november 8.) 
Lakner, Z. (szerk.) (2012) Sajátos nevelési igényüek pedagógiája és pszichológiája. Szent István Társulat az apostoli szentszék könyvkiadója, Budapest.

Lannert, J. (2004) Pályaválasz̧ási aspirációk. PhD értekezés. Budapesti Közgazdaságtudományi Egyetem, Budapest.

Liskó, I. (2003). Továbbtanulási ambiciók és esélyek. Educatio, 11. 2. 225-235.

Liskó, I. (2004). Perspektivák a középiskola után. Kutatás Közben sorozat, Felsőoktatási Kutatóintézet, Budapest.

Magyar Tudományos Akadémia Közigazgatási Intézet (2008). Az MTA-KTI „A közoktatás teljesitményének mérése-értékelése" programjának SNI 704. számú produktuma. Statisżtikai számitások a sajátos nevelési igényü tanulók iskolaválasztásának okairól és iskoláinak jellemróiról. MTA-KTI, Budapest.

Mező, F. \& Mező, K. (2015) A sajátos nevelési igényú (SNI) gyermekek tehetségének egyéni mentorálása. Tehetség 2. 3-5.

Mező, F. (2010). Tanulás: diagnosztikea és fejlesztés az IPOO-modell alatján. Debrecen. Kocka Kör Egyesület

Oktatási Hivatal (2008) Az algoritmus hétköznapi fogalmának megismerése. Informatika. Sulinet Tudásbázis.

Oktatáskutató és Fejlesztő Intézet (2009). Sajátos nevelési igény: A látássérülés, a ballássérïlés, a mozgáskorlátozottság, az autizmus, a beszédfogyatékosság, az értelmi fogyatékosság: Ami a kategóriák mögött van. www.ofi.hu (Letöltés: 2018. november 8.)
Olteanu, Lucián Líviusz (2015). A pályaválasztás rendszerszemléleti nézőpontból. Iskolakultúra. 25., 9. 45-55.

Szentes, E. (2016). A pályaszocializáció felsóoktatási lehetöségeinek vizsgálata. PhD értekezés. Eszterházy Károly Egyetem Neveléstudományi Doktori Iskola

Tóth, L. (2015) Sajátos nevelési igényü tanulók fejlesztése. Segédanyag a pedagógus szakvizsgára készülők számára. Debreceni Egyetemi Kiadó, Debrecen.

Török, R. (2016). A pályadöntési énhatékonyság sajátosságai és változási mintázatai sajátos nevelési igényü és tipikus fejlödésü középiskolások körében. Doktori értekezés. Budapest. ELTE-PPK

Török, R. (2017). A pályadöntések mesterei. ELTE Eötvös Pont Kiadó, Budapest.

\section{Jogszabályok:}

2011. évi CXC. törvény a nemzeti köznevelésről

15/2013. (II. 26.) EMMI rendelet a pedagógiai szakszolgálati intézmények működéséről

20/2012. (VIII. 31.) EMMI rendelet a nevelésioktatási intézmények működésérôl és a köznevelési intézmények névhasználatáról

A sajátos nevelési igényú, illetve a beilleszkedési, tanulási, magatartási nehézséggel küzdő tanulók részvétele a középfokú felvételi eljárásban. Oktatási Hivatal. www.oktatas.hu (Letöltve: 2018. augusztus 31.) 